\title{
KARAKTERISTIK PEDAGANG TRADISIONAL DI PASAR KEPATIHAN KABUPATEN JEMBER
}

\author{
Siti Muzdalifah', Sukidin' ${ }^{1}$, Pudjo Suharso ${ }^{1}$ \\ ${ }^{1}$ Program Studi Pendidikan Ekonomi, Fakultas Keguruan dan Ilmu Pendidikan Universitas Jember \\ E-mail: ipeifah@gmail.com
}

\begin{abstract}
Abstrak
Keberadaan pasar modern yang jumlahnya semakin banyak dikhawatirkan akan menggusur pasar tradisional yang ada. Meski demikian sampai saat ini masih ada beberapa pasar tradisional yang mampu mempertahankan eksistensinya. Pasar Kepatihan merupakan salah satu pasar tradisional di Kabupaten Jember yang mampu bertahan dan menjadi pasar yang disukai masyarakat sebagai tempat berbelanja. Pedagang tradisional di Pasar Kepatihan menjual barang dengan harga yang relatif mahal dibandingkan dengan pasar tradisional lainnya namun mereka tetap mampu menarik pembeli untuk berbelanja di pasar ini. Karakteristik pedagang tradisional di Pasar Kepatihan dapat dilihat melalui dua aspek yaitu pola komunikasi dan modal sosial pedagang. Tujuan penelitian ini adalah untuk mendeskripsikan karakteristik pedagang tradisional di Pasar Kepatihan Kabupaten Jember. Penelitian ini mengggunakan metode kualitatif dengan pendekatan deskriptif. Hasil penelitian menunjukkan bahwa pola komunikasi antara pedagang dan pembeli di Pasar Kepatihan dapat dilihat melalui interaksi dan komunikasi dalam aktivitas jual beli. Interaksi komunikatif pedagang dengan pembeli biasa umumnya terdapat tawar menawar harga sebelum terjadi kesepakatan, sedangkan interaksi komunikatif dengan pelanggan tidak terdapat tawar menawar harga namun diganti dengan pembicaraan di luar topik jual beli sebagai bentuk kedekatan hubungan. Sedangkan modal sosial yang dimiliki pedagang Pasar Kepatihan terdiri dari beberapa komponen. Adanya kepercayaan antara sesama pedagang maupun dengan pembeli yang dapat menjaga hubungan baik yang telah terjalin. Norma tidak tertulis di pasar yang dipatuhi oleh pedagang akan menciptakan suasana kondusif dan nyaman. Jaringan yang dibentuk pedagang dengan pemasok, sesama pedagang, dan pelanggan dapat menguntungkan pedagang untuk melanggengkan usahanya.
\end{abstract}

Kata Kunci: Pedagang tradisional, Karakteristik, Pola komunikasi, Modal sosial

\section{PENDAHULUAN}

Keberadaan pasar modern di Indonesia dari tahun ke tahun semakin banyak jumlahnya dan semakin meluas ke berbagai daerah. Hal ini juga terjadi di Kabupaten Jember salah satu kabupaten yang berada di wilayah provinsi Jawa Timur. Maraknya pasar modern dikhawatirkan akan menggusur pasar tradisional yang semakin ditinggalkan oleh masyarakat. Meski demikian di Kabupaten Jember masih terdapat beberapa pasar tradisional yang mempertahankan eksistensinya sampai saat ini. Pasar Kepatihan merupakan salah satu pasar tradisional di Kabupaten Jember yang mampu bertahan dan menjadi pasar yang disukai masyarakat sebagai tempat berbelanja. Pasar Kepatihan merupakan pasar pagi, setiap harinya pembeli selalu ramai berbelanja untuk memenuhi kebutuhannnya.

Pedagang Pasar Kepatihan mempunyai pola komunikasi yang sedikit berbeda dan unik dibandingkan dengan pasar tradisional pada umumnya yang identik semua transaksi dilakukan dengan adanya tawar menawar intensif, namun interaksi jual beli yang dilakukan sering tanpa adanya tawar menawar harga antara pedagang dan pembeli di Pasar Kepatihan. Meskipun begitu sebagai pasar tradisional dalam aktivitas ekonominya di Pasar Kepatihan tetap ada tawar menawar dalam interaksi jual beli karena tawar menawar sudah seperti tradisi di setiap pasar tradisional.

Menurut Belshaw (dalam Kusnadi dan Sumiati, 2016) dalam sistem perdagangan tradisional tidak mengindahkan aturan perdagangan pada umumnya namun lebih memperdulikan bagaimana terjadinya transaksi. Aktivitas dagang yang dilakukan pedagang tradisional tidak semata-mata mencari untung namun dapat pula terjadi rugi asalkan komunikasi dan hubungan kekerabatan tetap berjalan. Hal ini ditunjukkan oleh pedagang Pasar Kepatihan dengan memberikan potongan harga pada pelanggan tetap maupun memberikan bonus pada pembeli. Dengan adanya perilaku semacam ini maka pedagang dapat menjaga hubungan baik dengan pembeli. Selain itu pembeli yang berbelanja di pasar tradisional memungkinkan untuk menawar harga barang kepada pedagang sehingga mencapai kesepakatan harga, bahkan jika pembeli pandai menawar mereka dapat mendapat harga yang lebih murah dari pembeli lainnya.

Pedagang tradisional di Pasar Kepatihan dalam menjalankan usahanya selalu menyediakan barang yang berkualitas untuk dijual. Barang yang dijual di Pasar Kepatihan juga mempunyai variasi barang yang cukup banyak bila dibandingkan dengan pasar modern, misalnya seperti ikan maupun sayur. Selain itu sesama pedagang di Pasar Kepatihan umumnya mempunyai hubungan yang baik untuk saling mendukung dan saling menguntungkan dalam bidang pekerjaannya. Meskipun berkerja sebagai sesama pedagang pasar namun 
DOI:

pedagang di Pasar Kepatihan tidak saling menjatuhkan demi keuntungan pribadi. Relasi yang dijalin sesama pedagang tidak hanya berguna untuk sekedar mencari teman namun dengan adanya relasi ini usaha dan keberadaan pasar tradisional dapat tetap terjaga.

Komunikasi merupakan kegiatan yang penting dalam kehidupan sehari-hari. Sebagai makhluk sosial manusia akan selalu berkeinginan untuk berbicara, tukar-menukar argumen, mengirim dan menerima informasi, berbagi pengalaman, dan bekerja sama dengan orang lain sehingga berbagai keinginan tersebut dapat dilakukan melalui komunikasi. Menurut Suranto (2010:4) komunikasi adalah suatu proses pengiriman pesan atau simbolsimbol yang mengandung arti dari seorang komunikator kepada komunikan dengan tujuan tertentu. Selain komunikasi, interaksi sosial merupakan kunci dari kehidupan sosial, tanpa adanya interaksi sosial tidak mungkin ada kehidupan bersama. Interaksi sosial dan komunikasi menjadi suatu proses sosial yang sangat berpengaruh dalam kehidupan sehari-hari masyarakat.

Bentuk komunikasi dalam kehidupan sehari-hari ada beberapa jenis, salah satunya yaitu komunikasi antarpribadi (interpersonal communication), bentuk komunikasi ini memiliki karakter yang berbeda dari bentuk komunikasi lainnya. Mulyana (2015:81) mengungkapkan komunikasi antarpribadi adalah komunikasi antara orang-orang secara tatap muka yang memungkinkan untuk setiap orang menangkap reaksi orang lain secara langsung, baik secara verbal maupun nonverbal. Komunikasi antarpribadi memiliki topik bahasan sangat variatif, pihak yang berkomunikasi dapat membahas mengenai topik umum sampai ke khusus, misalnya pembicaraan mengenai humor, kondisi keluarga, maupun tentang bidang pekerjaan yang dijalani. Sehingga tidak masalah jika seseorang ingin menggunakan bahasa daerah, bahasa gaul, maupun bahasa campuran yang terpenting pesan yang ingin disampaikan dapat diterima dengan baik. Menurut Mubarok dan Andjani, 2014:75) aspek ekspektasi pribadi menjadi faktor penting yang mempengaruhi berlangsungnya komunikasi antarpribadi, pesan yang disampaikan dalam jenis komunikasi ini tidak hanya pesan verbal namun juga nonverbal, pesan dapat disampaikan melalui bentuk sentuhan, pandangan mata, mimik wajah maupun intonasi dalam menyampaikan kata-kata.

Seseorang akan senantiasa berkomunikasi dengan orang lain dalam kehidupan sehari-hari. Interaksi antarindividu dipengaruhi oleh simbol-simbol dan interpretasi untuk saling memahami maksud dari tindakan masing-masing yang dilakukan setiap individu. Simbol dapat berwujud dalam berbagai bentuk dan penting bagi kehidupan manusia karena mewakili makna yang ingin disampaikan. Dalam berkomunikasi manusia akan saling menerjemahkan tindakan-tindakan yang dilakukannya. Menurut Blumer (dalam Wibowo, 2015) interaksi simbolik menunjuk pada sifat khas dari interaksi antarmanusia yaitu manusia saling menerjemahkan dan saling mendefinisikan tindakannya. Teori interaksi simbolik melihat manusia adalah entitas sosial yang hidup dalam suatu kelompok. Melalui simbol-simbol khususnya dalam bentuk bahasa manusia dapat saling berkomunikasi.

Menurut Djamarah (dalam Saputra, 2014) pola komunikasi dapat dipahami sebagai pola hubungan antara dua orang atau lebih dalam pengiriman dan penerimaan pesan dengan cara yang tepat sehingga pesan yang dimaksud dapat dipahami. Proses komunikasi yang terjadi di pasar tradisional merupakan pola komunikasi sirkuler, dimana dalam pola komunikasi ini terdapat feedback secara langsung yaitu terjadinya arus komunikan ke komunikator sebagai penentu utama keberhasilan. Pola komunikasi sirkuler dapat dipahami melalui model komunikasi interaksional yang dikembangkan oleh Wilburm Schramm yang merujuk berdasarkan perspektif interaksi simbolik Herbert Blumer. Menurut Scrhramm (dalam Mulyana, 2015:151) komunikasi dianggap sebagai interaksi kedua pihak yang menyandi, menafsirkan, menyandi-balik, mentransmisikan, dan menerima sinyal, disini dilihat bahwa umpan balik dan lingkaran yang berkelanjutan untuk berbagi informasi. Menurut Rohim (2009:16) terdapat elemen yang penting disini yaitu umpan balik yang dapat berupa verbal maupun nonverbal, sengaja maupun tidak disengaja yang membantu pihak yang berkomunikasi untuk mengetahui apakah pesan dan makna yang disampaikan telah diterima dengan baik atau tidak.

Pedagang di pasar tradisional selalu menjaga hubungan baik dengan sesama pedagang lainnya, hal ini dilakukan untuk menjaga kenyamanan pembeli berbelanja maupun membuat suasana nyaman pedagang dalam berjualan. Menurut Coleman (2008:419-420) modal sosial terdapat di pasar tradisional, hal ini dapat dilihat dari tidak adanya batas antara para pedagang, dalam pasar relasi kekeluargaan memegang peranan penting, relasi semacam ini menggambarkan bahwa pasar dapat dilihat sebagai sebuah organisasi sosial atau bisa disebut toko serba ada yang hubungannya didasarkan pada suatu kebersamaan dimana setiap individu memiliki bagian modal sosial yang didasarkan pada relasi tersebut.

Bourdieu (dalam Sun'an dan Senuk, 2015:91) mendefinisikan modal sosial sebagai sumber daya yang dimiliki seseorang maupun kelompok dengan memanfaatkan jaringan atau hubungan yang terlembaga dan ada saling mengakui antar anggota yang terlibat di dalamnya. Menurut Coleman (2008:420-422) modal sosial tercipta ketika relasi antara orang-orang mengalami perubahan sesuai sesuai dengan cara-cara yang memudahkan tindakan. Coleman melihat modal sosial seperti modal ekonomi yang bersifat produktif, tanpa adanya modal sosial seseorang tidak akan bisa memperoleh keuntungan material dan mencapai keberhasilan lainnya secara optimal. Modal sosial melibatkan kewajiban dan ekspektasi yang melibatkan jaringan lebih luas sehingga hubungannya diatur oleh tingginya tingkat kepercayaan dan nilai-nilai bersama. Modal sosial 
DOI:

merupakan sarana untuk menjelaskan bagaimana orang berusaha bekerja sama untuk mengejar kepentingan mereka sendiri dimana interaksi sosial dipandang sebagai bentuk pertukaran.

Secara umum ada beberapa komponen utama yang mengendap dalam modal sosial. Menurut Coleman (2008:423) kepercayaan dalam modal sosial merupakan kewajiban dan ekspektasi, jika seseorang melakukan sesuatu untuk orang lain maka orang tersebut akan percaya bahwa suatu saat akan mendapat balasan pada masa depan dari orang lain tersebut, hal ini akan menciptakan ekspektasi dan kewajiban untuk memelihara kepercayaan, dari sini dapat dipahami bahwa kewajiban akan dilunasi dan tingkat kewajiban aktual tersebut akan dipegang. Norma dan sanksi efektif sebagian besar didukung dengan penghargaan eksternal untuk tindakan tanpa pamrih dan penolakan terhadap tindakan egois, selain itu norma juga didukung dengan sanksi internal atau sanksi eksternal. Coleman (dalam Sun'an dan Senuk, 2015:91) mengungkapkan norma bersama belum cukup untuk menjamin kerja sama antar individu karena bisa ada yang tidak taat terhadap aturan oleh karena itu diperlukan sanksi sosial yang bersifat informal sehingga hubungan dan interaksi sosial dapat terjaga dengan baik.

Jaringan merupakan ikatan antarindividu atau antarkelompok yang dihubungkan melalui hubungan sosial yang diikat dengan kepercayaan. Hubungan antar pedagang tradisional mengutamakan sikap saling menghormati, tolong menolong, toleransi untuk membina hubungan baik sesama pedagang. Selain itu hubungan pedagang dan pembeli juga harus saling menguntungkan, oleh karena itu biasanya para pedagang berusaha untuk mempunyai pembeli tetap (pelanggan). Sunyoto Usman (2013:76) membedakan modal sosial yang ada di pedagang tradisional meliputi 2 jenis. Pertama, bounding social capital merupakan bentuk modal sosial yang memperhatikan kesamaan dan memungkinkan jaringan kerja sama antar anggota dalam kelompok, dalam ikatan bounding aktor sosial diikat berdasarkan tempat tinggal, kekerabatan, agama, etnis, dan adat istiadat yang lebih suka mengedepankan face-to-face relationship. Kedua, bridging social capital melihat hubungan anggota suatu kelompok dengan kelompok lain dan bukan hanya melihat hubungan dengan sosial anggota dalam kelompok yang sama. Dalam bridging social capital aktor sosial diikat menembus tempat tinggal, kekerabatan, etnis, agama dan adat istiadat. Sehingga relasi-relasi sosial yang terjadi dapat menggunakan teknologi informasi dan komunikasi.

\section{METODE}

Penelitian ini merupakan penelitian kualitatif dengan jenis pendekatan deskriptif. Penelitian kualitatif dengan jenis pendekatan deskriptif bertujuan untuk menggambarkan suatu keadaan atau situasi yang berjalan pada saat penelitian dilakukan. Lokasi penelitian dalam penelitian dilakukan secara sengaja di Pasar Kepatihan, Kecamatan Kaliwates, Kabupaten Jember. Dalam pengumpulan data peneliti menggunakan metode wawancara dan observasi partisipasi. Analisis data yang digunakan dalam penelitian terdiri atas beberapa tahap, yaitu reduksi data, penyajian data dan penarikan kesimpulan.

\section{HASIL DAN PEMBAHASAN Hasil Penelitian}

Pada bab ini peneliti akan menggambarkan hasil penelitian selama wawancara dan melakukan observasi pastisipasi sekaligus membahas tentang karakteristik pedagang tradisional melalui pola komunikasi dan nilainilai kebersamaan pedagang.

\section{Pola Komunikasi antara Pedagang dan Pembeli}

Pola komunikasi pedagang dan pembeli di Pasar Kepatihan dapat dipahami melalui interaksi jual beli antara pedagang dengan pembeli biasa maupun dengan pelanggan. Pola komunikasi di Pasar Kepatihan dilihat sebagai komunikasi yang berlangsung secara terus menerus antara pedagang dan pembeli secara tatap muka secara bergiliran sehingga terjadi feedback secara langsung. Bahasa yang digunakan dalam interaksi jual beli di Pasar Kepatihan tergantung dari pedagang dan pembeli itu sendiri, bisa menggunakan bahasa Indonesia, bahasa Jawa, maupun bahasa Madura. Selain menggunakan bahasa verbal, komunikasi antara pedagang dan pembeli di Pasar kepatihan juga menggunakan pesan-pesan non verbal untuk melakukan interaksi jual beli. Tampilan luar pembeli ketika berbelanja memberikan informasi kepada pedagang berasal dari kalangan atau etnis apa. Tatapan mata pembeli ketika melihat barang dagangan secara tidak langsung membuat pedagang spontan menawari atau menanyai pembeli tersebut karena biasanya pembeli berhenti di depan tempat jualan atau los pedagang ketika tertarik dengan barang yang dijual. Begitu juga dengan ekspresi pedagang yang berusaha meyakinkan pembeli bahwa harga barangnya sesuai dengan kualitas, seperti gerakan tangan memperlihatkan produk dengan mengangkatnya hal itu dilakukan untuk meyakinkan barang yang dijual bagus dan berkualitas sehingga harganya cocok.

Pembeli di Pasar Kepatihan kebanyakan merupakan orang-orang yang berbelanja untuk dikonsumsi pribadi sehingga jarang melakukan tawar menawar. Pembeli yang sudah mengetahui kualitas barang yang dijual 
DOI:

dan sering berbelanja di pasar tidak merasa kaget dengan harga yang ditawarkan oleh pedagang kepada mereka. Pembeli yang berbelanja tanpa menawar harga umumnya merupakan pelanggan yang sering belanja dan sudah mengetahui harga pasaran di Pasar Kepatihan. Namun berbeda dengan pembeli baru, jika yang berbelanja merupakan pembeli baru maka biasanya terdapat proses tawar menawar di dalamnya karena pembeli baru tidak mengetahui harga pasaran dan tidak terbiasa berbelanja disini.

Barang yang dijual di Pasar Kepatihan memang umumnya mempunyai harga yang relatif lebih mahal dibanding dengan harga di pasar tradisional lainnya, oleh karena itu pembeli baru yang biasanya tidak berbelanja disini merasa kaget dan langsung menawar harga pada pedagang. Ketika terjadi tawar menawar pedagang dan pembeli adu argumentasi menentukan harga yang cocok dan menguntungkan bagi keduanya. Pedagang tradisional di Pasar Kepatihan mempunyai cara untuk menanggapi pembeli yang menawar murah yaitu memberikan informasi dan meyakinkan pembeli tentang kualitas barang sehingga harga yang ditawarkan merupakan harga yang sesuai. Namun ada pedagang juga yang sering melakukan tawar menawar dengan pembeli, hal ini dilakukan berdasarkan kondisi barang yang dijual, misalnya pedagang ikan. Mereka sering melakukan tawar menawar dengan pembeli agar barang dagangannya cepat habis, karena kalau tidak habis pada hari itu juga maka kualitas barang akan menurun dan malah akan turun harganya jika dijual keesokan harinya.

Ketika berbelanja di pasar tradisional dan berkomunikasi secara langsung tidak heran jika percakapan antara pedagang dan pembeli tidak hanya mengenai ekonomi semata namun juga terdapat bahasan diluar topik interaksi jual beli apalagi kepada pelanggan tetap yang sudah kenal baik, maka pedagang dan pelanggan tersebut membahas berbagai macam topik mulai dari sekedar gosip, kondisi masing-masing, sampai seputar keluarga. Komunikasi yang intens ini menimbulkan keakraban dan kedekatan emosional antara pedagang dan pembeli. Beberapa alasan yang digunakan oleh pedagang ketika melakukan percakapan mengenai hal lain di luar jual beli adalah untuk mengakrabkan diri dengan pembeli, memudahkan transaksi, dan mencairkan suasana sehingga suasana menjadi lebih nyaman.

\section{Mengembangkan Nilai-Nilai Kebersamaan antar Pedagang}

Kepercayaan merupakan unsur utama yang digunakan untuk membangun sebuah hubungan antara dua individu atau lebih, terutama dalam kerjasama. Kepercayaan dapat diwujudkan dalam bentuk kejujuran, keramahan dan saling menghormati. Pedagang Pasar Kepatihan memiliki kesadaran bahwa kepercayaan harus dijaga agar hubungan dengan sesama pedagang maupun dengan pembeli dapat terjaga dengan baik. Kepercayaan tersebut dapat diwujudkan dalam sikap maupun perilakunya, misalnya dalam beraktivitas pedagang jujur terhadap kualitas barang, harga dan lain sebagainya. Sesama pedagang tidak saling menipu dalam hal usaha sehingga kepercayaan telah membuat sesama pedagang saling membantu, misalnya pedagang di Pasar Kepatihan membuat sebuah arisan bersama, sistem arisan seperti ini tentu tidak dapat terwujud bila tidak adanya kepercayaan antar pedagang karena dalam sistem arisan pedagang yang mendapat uang di awal tentu bisa tidak membayar setelahnya dan merugikan pedagang lain, namun karena adanya kewajiban dan ekspektasi maka hal ini tidak terjadi. Oleh karena itu dalam sistem seperti ini kepercayaan mempunyai peran yang sangat penting agar tidak merugikan sesamanya.

Norma sosial merupakan suatu bentuk aturan yang berorientasi dari norma budaya, agama, maupun kearifan lokal yang sudah berkembang dalam lingkungan masyarakat. Norma yang ada di Pasar Kepatihan merupakan norma yang menjadi acuan pedagang dalam bertindak, contohnya adanya keyakinan bahwa rejeki sudah ada yang mengatur telah membentuk perilaku para pedagang agar tidak saling menjatuhkan, iri terhadap keberhasilan pedagang lain malah sebaliknya mereka saling menolong dan mendukung. Pedagang di Pasar Kepatihan dalam hubungannya selalu mengedepankan rasa saling menghormati dan saling menghargai sesama pedagang, sehingga dengan adanya ini hubungan dapat terjaga dengan baik dan tidak menyebabkan kekacauan antar pedagang di pasar. Selain itu sesama pedagang pasar telah menumbuhkan rasa kekeluargaan, perasaan tersebut memungkinkan mereka saling bertukar kebaikan, misalnya jika ada pedagang yang tidak berjualan karena sakit maka pedagang lain menjenguk. Selain itu jika ada pembeli yang datang untuk membeli suatu barang namun barang tersebut habis maka dicarikan ke pedagang lainnya, dan berkaitan dengan pembayarannya pedagang yang dipinjami tidak mematok harga yang harus dikembalikan oleh pedagang yang meminjam. Namun jika terdapat pedagang yang bertindak egois maka secara tidak langsung pedagang lainnya merasa kesal sehingga menjauh dan kurang memeperhatikan keberadaannya.

Jaringan dalam dunia usaha merupakan suatu hal yang sangat penting, seseorang yang tidak memiliki jaringan maka usahanya tidak berjalan dengan lancar bahkan bisa berhenti atau gagal. Bentuk jaringan yang dijalin oleh pedagang di Pasar Kepatihan beraneka ragam tergantung pada jenis barang yang dijual. Jaringan tersebut dibutuhkan untuk kepentingan berdagang di pasar. Pedagang pasar biasanya menciptakan jaringan dengan pemasok, misalnya untuk pedagang daging akan memakan waktu yang lama jika mereka memotong sendiri hewan untuk barang dagangannya setiap hari. Jadi kebanyakan pedagang memilih mengambil dari pemasok yang dapat mengantarkan barang dagangan tiap kali stok habis. Selain menciptakan jaringan dengan pemasok, pedagang Pasar Kepatihan juga membangun hubungan yang baik dengan sesama pedagang, seorang 
DOI:

pedagang pasar tidak bisa menyediakan semua jenis barang sendiri sehingga hubungan baik dengan sesama pedagang perlu dilakukan untuk saling membantu jika terdapat kesulitan sekaligus untuk memperlancar usahanya. Pedagang Pasar Kepatihan juga berupaya mencari pelanggan, hal ini juga bagian dari mencari jaringan sosial. Bagi pedagang membangun hubungan dengan pembeli dan pelanggan merupakan hal sangat penting, dengan membangun hubungan baik dan menjaganya diharapkan pedagang mendapatkan pelanggan yang terus berbelanja di tempatnya dan tidak berpindah ke pedagang lainnya.

\section{Pembahasan}

Pola Komunikasi antara pedagang dan pembeli di Pasar Kepatihan dapat dilihat melalui interaksi dan proses komunikasi dalam aktivitas jual beli. Interaksi komunikatif pedagang dengan pembeli dapat dibagi menjadi dua macam yaitu interaksi komunikatif dengan pembeli biasa (baru) dan interaksi komunikatif dengan pelanggan. Interaksi komunikatif pedagang dengan pembeli biasa umumnya terdapat tawar menawar harga sebelum terjadi kesepakatan, sedangkan interaksi komunikatif dengan pelanggan tidak terdapat tawar menawar harga namun diganti dengan pembicaraan di luar topik jual beli sebagai bentuk kedekatan hubungan. Pola komunikasi antara pedagang dan pembeli di Pasar Kepatihan merupakan pola komunikasi sirkuler dimana terjadi komunikasi secara terus menerus antara pedagang dan pembeli secara tatap muka sehingga terjadi feedback secara langsung. Hal ini seperti diungkapkan oleh Schramm (dalam Mulyana, 2015:151) bahwa dalam pola ini komunikasi dianggap sebagai interaksi kedua pihak yang menyandi, menafsirkan, menyandi-balik, mentransmisikan, dan menerima sinyal, di sini dilihat bahwa umpan balik dan lingkaran yang berkelanjutan untuk berbagi informasi.

Komunikasi antara pedagang dan pembeli di pasar dalam aktivitas jual beli memungkinkan terjadinya feedback secara langsung saat itu juga, sehingga pedagang maupun pembeli dapat secara langsung menangkap reaksi dari lawan bicara dan dapat langsung merespon balik kembali, seperti yang diungkapkan oleh Rohim (2009:16) bahwa terdapat elemen yang penting disini yaitu umpan balik yang dapat berupa verbal maupun nonverbal, sengaja maupun tidak disengaja yang membantu pihak yang berkomunikasi untuk mengetahui apakah pesan dan makna yang disampaikan telah diterima dengan baik atau tidak.

Penggunaan bahasa Indonesia, bahasa Jawa, dan bahasa Madura dilakukan pedagang dan pembeli di Pasar Kepatihan demi kelancaran komunikasi, jika pembeli yang berbelanja menggunakan bahasa Jawa atau Madura maka pedagang menanggapi dengan bahasa yang sama agar pesan yang disampaikan dapat lebih mudah dimengerti. Dalam melakukan interaksi jual beli di pasar pedagang dan pembeli dapat saling memahami simbol dan pesan yang dipertukarkan, sehingga dalam berkomunikasi feedback dapat diberikan langsung. Hal ini sesuai dengan pendapat Blumer (dalam Wibowo 2015) bahwa interaksi simbolik menunjuk pada sifat khas dari interaksi antarmanusia yaitu manusia saling menerjemahkan dan saling mendefinisikan tindakannya. Disini pedagang dan pembeli sama-sama memahami maksud dari masing-masing pihak melalui bahasa dan simbolsimbol yang digunakan. Misalnya ketika pembeli menunjukkan raut wajah ragu maka pedagang tanpa diberitahu apa yang sedang dipikirkan pembeli tersebut sehingga pedagang berusaha meyakinkan pembeli tersebut untuk membeli.

Komunikasi yang terjadi di Pasar Kepatihan tidak hanya bertujuan untuk ekonomi semata namun terdapat berbagai topik pembicaraan mulai dari jual beli bahkan sampai topik diluar jual beli, oleh karena itu dapat diketahui bahwa komunikasi disini berbentuk komunikasi antarpribadi. Interaksi antara pedagang dan pelanggan yang tidak ada proses tawar menawar dalam interaksinya terdapat pemberian dan penerimaan pesan yang membahas topik diluar aktivitas jual beli, misalnya pembicaraan tentang keluarga maupun tentang lainnya. Hal ini memunculkan hubungan antarpersonal melalui kedekatan emosional antara pedagang dan pelanggan. Seperti yang diungkapkan oleh Mulyana (2015:81) bahwa komunikasi antarpribadi adalah komunikasi antara orang-orang secara tatap muka yang memungkinkan untuk setiap orang menangkap reaksi orang lain secara langsung, baik secara verbal maupun non verbal. Selain itu komunikasi antarpribadi mempunyai topik bahasan yang variatif.

Hubungan dengan sesama pedagang di Pasar Kepatihan dianggap sangat penting karena dengan menjalin hubungan yang baik dengan sesama dapat melancarkan usahanya karena sesama pedagang saling membantu dan saling menolong jika terdapat kesulitan. Kerukunan sesama pedagang perlu dilakukan karena bagi mereka hal tersebut secara tidak langsung dapat menarik pembeli di pasar. Sesama pedagang saling memahami dan menjaga kerukunan untuk membuat pembeli nyaman berbelanja di pasar Kepatihan, misalnya seorang pedagang yang menjual suatu barang jenis tertentu ketika ditanya dimana dapat menemukan barang dagangan yang sejenis mau memperkenalkan ke pedagang lain yang berjualan barang sejenis kepada pembeli, bahkan mereka tidak ragu untuk mengantarkan ke tempat pedagang lainnya. Hubungan semacam ini dapat disebut sebagai modal sosial, seperti yang diungkapkan oleh Coleman (2008:419-420) bahwa modal sosial terdapat di pasar tradisional, hal ini dapat dilihat dari tidak adanya batas antara para pedagang, dalam pasar relasi kekeluargaan memegang peranan penting, relasi semacam ini menggambarkan bahwa pasar dapat dilihat sebagai sebuah organisasi sosial atau bisa disebut toko serba ada yang hubungannya didasarkan pada suatu kebersamaan dimana setiap individu 
DOI:

memiliki bagian modal sosial yang didasarkan pada relasi tersebut.

Pedagang Pasar Kepatihan dalam berjualan selalu mengutamakan kejujuran, karena kejujuran melandasi sikap saling mempercayai dan saling menghargai yang merupakan syarat mendasar berlangsungnya kegiatan jual beli agar hubungan kerjasama yang sudah terjalin lama tetap terjaga dengan baik. Pedagang percaya jika mereka memperlakukan sesama pedagang maupun pembeli dengan baik maka orang tersebut juga akan bersikap baik juga. Hal ini seperti diungkapkan oleh Coleman (2008:423) bahwa kepercayaan dalam modal sosial merupakan kewajiban dan ekspektasi, jika seseorang melakukan sesuatu untuk orang lain maka orang tersebut akan percaya bahwa suatu saat akan mendapat balasan pada masa depan dari orang lain tersebut.

Adanya norma telah mengatur kehidupan para pedagang di Pasar Kepatihan. Norma di Pasar Kepatihan tidak tertulis namun norma ini telah ada sejak dulu dan turun menurun di kalangan pedagang. Norma itu mengacu pada pandangan hidup mereka berkaitan dengan pedagang, jika norma ini tidak ada tentu kehidupan pedagang menjadi kacau. Norma tidak tertulis ini mengacu pada sikap saling menghormati dan menghargai sesama pedagang tradisonal di pasar, sehingga jika terdapat pedagang yang bersikap egois maka pedagang lain akan kesal dan menjauhinya. Hal ini diungkapkan oleh Coleman (dalam Sun'an dan Senuk, 2015:91) bahwa norma bersama belum cukup untuk menjamin kerja sama antar individu karena bisa ada yang tidak taat terhadap aturan oleh karena itu diperlukan sanksi sosial yang bersifat informal sehingga hubungan dan interaksi sosial dapat terjaga dengan baik.

Pedagang Pasar Kepatihan membentuk suatu jaringan yang beraneka ragam tergantung jenis dagangannya. Pedagang membentuk jaringan dengan pemasok untuk memudahkan mereka mendapatkan barang dagangan. Selain itu jaringan yang lain juga dibangun pedagang Pasar Kepatihan dengan sesama pedagang, dengan hubungan baik dengan sesama pedagang jika seorang pedagang mengalami kesulitan maka pedagang lainnya dapat membantu, hal ini juga berlaku jika stok barang habis maka dapat meminjam dulu barang dagangan ke pedagang lain sejenis. Hal ini dilakukan untuk saling membantu dalam berjualan dan melancarkan usahanya. Jaringan lain yang dibentuk oleh pedagang Pasar Kepatihan yaitu dengan pelanggan, jika pedagang mempunyai pelanggan tetap memberikan perasaan nyaman kepada para pedagang bahwa barang dagangannya laku dan mengurangi kekhawatirannya untuk rugi.

Pedagang di Pasar Kepatihan selalu menjaga hubungan baik dengan sesama pedagang hal ini dilakukan karena adaya perasaan senasib, pedagang pasar akan menganggap pedagang lainnya seperti teman dan keluarga, sehingga antara pedagang yang satu dengan yang lain saling menolong dan tidak saling menjatuhkan. Selain itu pedagang mencoba untuk membuat jaringan yang lebih luas karena didorong oleh faktor ekonomi, artinya mereka harus membuat jaringan dengan para pemasok atau tempat kulakan, dengan demikian para pedagang dapat memperoleh barang dagangan untuk dijual kembali di pasar. Hal ini sesuai dengan yang diungkapkan oleh Usman (2013:76) bahwa modal sosial di pasar tradisional dapat dibagi menjadi modal sosial bounding dan modal sosial bridging. Modal sosial bounding merupakan bentuk modal sosial yang mengikat dengan memperhatikan kesamaan dan memungkinkan jaringan kerja sama antar anggota dalam kelompok. Sedangkan bridging social capital melihat hubungan anggota suatu kelompok dengan kelompok lain dan bukan hanya melihat hubungan sosial dengan anggota dalam kelompok yang sama.

\section{PENUTUP}

Berdasarkan penelitian yang telah dilakukan, maka saran yang dapat diberikan peneliti adalah sebaiknya pemerintah secepatnya melakukan renovasi terhadap sarana fisik Pasar Kepatihan, mengingat pasar ini merupakan pasar yang sangat disukai masyarakat sebagai tempat berbelanja dan belum pernah tersentuh perbaikan sekalipun. Selain itu sebaiknya pedagang pasar tradisional lainnya juga mengutamakan kualitas barang seperti pedagang Pasar Kepatihan, agar pasar tradisional tetap digemari masyarakat dan dapat besaing dengan kualitas barang di pasar modern.

\section{DAFTAR PUSTAKA}

Coleman, J. S. 2008. Dasar-Dasar Teori Sosial. Bandung: Nusa Media

Mubarok dan M. D. Andjani. 2014. Komunikasi Antarpribadi dalam Masyarakat Majemuk. Jakarta: Dapur Buku

Mulyana, D. 2015. Ilmu Komunikasi: Suatu Pengantar. Bandung: Remaja Rosdakarya

Rohim, S. 2009. Teori Komunikasi: Perspektif, Ragam, dan Aplikasi. Jakarta: Rineka Cipta

Saputra, S. D. 2014. Komunikasi Tawar-Menawar Dalam Perdagangan (Studi Deskriptif Kualitatif Pola Komunikasi Tawar Menawar Pada Penjual Dan Pembeli Di Pasar Klewer Surakarta). skripsi. Surakarta: 
DOI:

Fakultas Ilmu Sosial dan Politik Universitas Sebelas Maret.

Sumiyati, S dan Kusnadi. 2016. Strategi Pedagang Pasar Tradisional dalam Persaingan dengan Pasar Modern di Kota Tangerang Selatan, Banten. Laporan penelitian. Universitas Terbuka

Sun'an, M. dan A. Senuk. 2015. Ekonomi Pembangunan Daerah. Jakarta: Mitra Wacana Media

Suranto. 2010. Komunikasi Sosial Budaya. Yogyakarta: Graha Ilmu

Usman, S. 2015. Esai-Esai Sosiologi Perubahan Sosial. Yogyakarta: Pustaka Belajar

Wibowo, R. P. 2015. Pola-Pola Komunikasi antara Penjual dan Pembeli di Pasar Kalipait Kecamatan Tegaldlimo Kabupaten Banyuwangi (Suatu Tinjauan Etnografi Komunikasi). skripsi. Jember: Fakultas Sastra Universitas Jember. 